The Israeli Journal of Aquaculture - Bamidgeh, IJA_69.2017.1365, 10 pages.

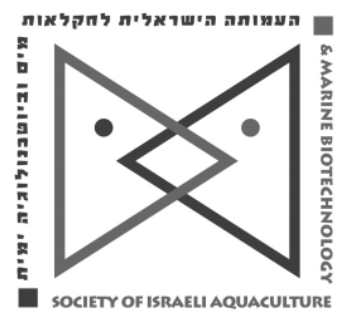

The IJA appears exclusively as a peer-reviewed on-line open-access journal at http://www.siamb.org.il. To read papers free of charge, please register online at registration form.

Sale of IJA papers is strictly forbidden.

\title{
In Vitro Activation of Epinephelus Malabaricus Head- Kidney Leukocytes by Angelica Sinensis Polysaccharide
}

\author{
Qingkui Wang ${ }^{1}$, Hong $\mathrm{Yu}^{1}$, Xueliang Sun ${ }^{1}$, Kezhi Xing ${ }^{1 *}$, Chengxun Chen ${ }^{1}$, \\ Yongjun Guo ${ }^{1}$ \\ ${ }^{1}$ Tianjin Key Laboratory of Aqua-ecology and Aquaculture, College of Fisheries, Tianjin \\ Agricultural University, 22 Jinjing Road, 300384 Tianjin, China
}

Keywords: Angelica sinensis polysaccharide; bactericidal activity; Epinephelus malabaricus; leukocytes proliferation; phagocytic activity; respiratory burst

\begin{abstract}
Phagocytic, respiratory burst, bactericidal, and proliferative activity stimulation of Epinephelus malabaricus head-kidney leukocytes by Angelica sinensis polysaccharide (ASP) were evaluated in vitro. Leukocytes were incubated for 2, 6, 12 and $24 \mathrm{~h}$ in the presence of $0,10,100$ and 1000 $\mu \mathrm{g} / \mathrm{mlASP}$ or $100 \mu \mathrm{g} / \mathrm{ml}$ lipopolysaccharide (LPS) before phagocytic and respiratory burst activity assay, and for $24 \mathrm{~h}$ with $0,100,1000,10000 \mu \mathrm{g}$ $\mathrm{ASP} / \mathrm{ml}$ before bactericidal activity detection. Meanwhile, leukocytes were incubated for 24 and $48 \mathrm{~h}$ followed by proliferative activity evaluation. The results showed that ASP boosted leukocytes phagocytic, respiratory burst, bactericidal, and proliferative activity significantly in a dose-dependent manner. Leukocytes incubated with $100 \mu \mathrm{g} / \mathrm{ml}$ ASP exhibited the highest phagocytic and respiratory burst activity. Leukocytes incubated with 1000 $\mu \mathrm{g} / \mathrm{ml}$ ASP showed the highest bactericidal activity, which was followed by leukocytes incubated with $100 \mu \mathrm{g} / \mathrm{ml}$ ASP. Leukocyte proliferation was significantly enhanced with increasing concentration of ASP, and reached the highest value with $10000 \mathrm{\mu g} / \mathrm{ml}$ ASP. Compared with LPS in the same concentration $(100 \mu \mathrm{g} / \mathrm{ml})$, ASP exerted a stronger stimulating effect on respiratory burst but was weaker on proliferation in $E$. malabaricus leukocytes. These findings indicate that ASP prototype enhanced cellular immunity of E. malabaricus, and potentially contributed to the pursuit of environmentally friendly prophylactic measures to enhance the immunity of $E$. malabaricus.
\end{abstract}

* Corresponding author. email: kzxing6668@126.com 


\section{Introduction}

Epinephelus malabaricus is high quality seafood found in tropical waters throughout the Indo-West Pacific areas from East Africa to the Tonga Islands. In the Asia-Pacific region, it has become one of the most important cultured marine fishes, due to its tolerance to intensive culture conditions, rapid growth, large size, desirable taste, and high market demand. However, grouper culture has encountered outbreaks of various infectious diseases caused by virus, bacteria, and parasites. A review of grouper health, pointed out that the use of herbal medicine as a more environmentally friendly technique has achieved remarkable success in disease management (Harikrishnan et al. 2011). Herbal medicines and their extracts are considered promising immunostimulants, due to their easy availability, broad spectrum activity, high effectiveness, and eco-friendly prophylactic measures (Bhuvaneswari and Balasundaram, 2006). A wide variety of herbs and herbal extracts as immunostimulants have been used in aquaculture (Van Hai 2015).

Angelica sinensis polysaccharide (ASP) exists in the root of traditional Chinese herbal medicine Angelica sinensis (Oliv.) Diels. Biological activities, and correlation of structure and biological activities of ASP as well as extraction and purification techniques have been reviewed (Jin et al. 2012). They concluded that ASP exhibits various important bioactive properties including antioxidant, antitumor (Cao et al., 2010), hematopoietic, hepatoprotective (Ye et al., 2001), immunomodulatory (Yang et al., 2008), radioprotective activity as well as gastrointestinal protective effects on terrestrial animals. Several in vitro studies demonstrated that ASP prototype triggered immune responses in mice (Chen et al., 2010). However, there is limited data regarding the immunomodulatory function of ASP in fish. Dietary supplementation of ASP was found to enhance disease resistance in E. malabaricus against Edwardsiella tarda as well as phagocytosis, proliferation, and respiratory burst activity of head kidney leukocytes (Wang et al 2012).

The objective of the present study was to examine the in vitro effects of ASP prototype on E. malabaricus leukocyte phagocytic, respiratory burst, bactericidal, and proliferative activity.

\section{Materials and methods}

Fish and ASP. Thirty healthy groupers (initial mean weight $406 \pm 12 \mathrm{~g}$ ) were sampled from a culture tank $(6.0 \mathrm{~m} \times 6.0 \mathrm{~m} \times 1.2 \mathrm{~m})$ in a recirculating system (Haifa Seafood Industrial Development Co., Ltd) in Tianjin, China. Fish were fed a commercial feed (Haiqi $^{\circledR}$ formulated feed for grouper, protein $\geq 52 \%$, and lipid $\geq 12 \%$, twice daily (7:30 am and 16:30 pm). The recirculating system consisted of a sieve bend screen, reservoir, biological filter, supplemental aeration, and circulation pump. The sieve bend screen was used to remove fish feces from seawater and maintain water quality. Water was renewed once a day at a rate of $2 \%$ of the system volume. Water temperature was maintained at $28.2 \pm 0.4{ }^{\circ} \mathrm{C}$, salinity at $33.1 \pm 1.2 \%$, dissolved oxygen at $8.5 \pm 0.2 \mathrm{mg} / \mathrm{L}, \mathrm{pH} 7.8 \pm$ 0.2 , ammonia below $0.12 \mathrm{mg} / \mathrm{L}$, and nitrite below $0.07 \mathrm{mg} / \mathrm{L}$. The light intensity was less than $500 \mathrm{Ix}$ and the photoperiod maintained at $12 \mathrm{~h}$ light/12 h dark cycle. The ASP was obtained according to the method described by Wang et al. (2011a). Total sugar, reducing sugar, uronic acid, and protein in the ASP were $76.72 \pm 1.70 \%, 4.02 \pm 0.12 \%$, $13.82 \pm 0.41 \%$, and $4.87 \pm 0.05 \%$, respectively.

Preparation of glutaraldehyde-fixed rabbit red blood cells (GRRBCs). GRRBCs were prepared according to Wang et al. (2011a). Prior to use, GRRBCs were re-suspended in RPMI-1640 (Gibco, USA) maintenance medium (mRPMI) with 5\% fetal bovine serum (FBS, Zhejiang Tianhang Biotechnology Co., Ltd., Zhejiang, China), $100 \mathrm{IU} / \mathrm{mL}$ ampicillin (Genview, Florida, USA), $0.1 \mathrm{mg} / \mathrm{mL}$ streptomycin sulfate (Genview, Florida, USA), counted in a Neubauer hemocytometer, and calibrated to $1.8 \times 10^{7}$ cells $/ \mathrm{ml}$.

Isolation of head-kidney leukocytes. Ten fish at a time were anesthetized with 100 mg/L MS-222 (Hangzhou Animal Pharmaceuticals Company, Zhejiang, China). Blood was drawn from the caudal vein with a $5 \mathrm{ml}$ syringe, put into $1.5 \mathrm{ml}$ Eppendorf tubes, left to clot overnight at $4^{\circ} \mathrm{C}$. Sera were pooled together and stored at $-85^{\circ} \mathrm{C}$ for later use. The anesthetized fish were sterilized with $75 \%$ ethanol $(\mathrm{v} / \mathrm{v})$. Head-kidney was aseptically 
excised, rinsed with sterilized $0.85 \%$ sodium chloride solution, and cut into $5-10 \mathrm{~mm}^{3}$ pieces with sterilized scissors. The head-kidney fragments were mixed with $5 \mathrm{ml}$ of RPMI1640 medium contained $20 \mathrm{IU} / \mathrm{mL}$ heparin sodium (Solarbio, Beijing, China), $100 \mathrm{U} / \mathrm{mL}$ ampicillin, $0.1 \mathrm{mg} / \mathrm{mL}$ streptomycin sulfate, transferred to a sterilized $150 \mu \mathrm{m}$ stainless steel mesh. Cell suspension was obtained by forcing the fragments through the mesh with a syringe rod. The resulting cell suspension was centrifuged $\left(400 \mathrm{~g}, 4^{0} \mathrm{C}\right)$ for $10 \mathrm{~min}$. The cell precipitation was washed $\left(400 \mathrm{~g}, 4^{\circ} \mathrm{C}, 10 \mathrm{~min}\right)$ three times with phosphate buffer solution (0.1 M PBS, pH 7.4). After three washes, the cells were resuspended in mRPMI, placed on a 1.020/1.059 Percoll (Sigma, Beijing, China) density gradient, and centrifuged at $400 \mathrm{~g}$ for $25 \mathrm{~min}$ at $4^{\circ} \mathrm{C}$. The isolated cells at the Percoll interface were collected and washed twice with mRPMI. Cell viability was examined by trypan blue (Sigma, Beijing, China) exclusion in a Neubauer hemocytometer. In all samples, cell viability was greater than $96 \%$. The leukocytes were calibrated to $2 \times 10^{7}$ cells $/ \mathrm{mL}$ of $\mathrm{mRPMI}$ for later use. The leukocytes of 10 fish were mixed together as one pooled sample. In total, three pooled samples were used to assay the phagocytic, respiratory burst, bactericidal, and proliferation activities.

Phagocytic activity. Phagocytic activity was measured according to the method described by Wang et al. (2011a) and Gebran et al. (1992) with some modifications. Cell suspension was calibrated to $5 \times 10^{7}$ cells $/ \mathrm{mL}$ in RPMI-1640 solution. One hundred microliters of leukocytes suspension were placed in wells $(n=6)$ of a flat-bottomed 96well cell culture plate, and incubated for $3 \mathrm{~h}$ in a humidified incubator (Heracell ${ }^{\mathrm{TM}} 150 \mathrm{i}$, Thermo Scientific) containing $5 \% \mathrm{CO}_{2}$. Non-adherent cells were removed by washing the cultures twice with phenol red-free Hank's balance salt solution (HBSS, Beijing Dingguo Changsheng Biotech. Co. Ltd., Beijing, China). The remaining monolayer was incubated for $2,6,12$, or $24 \mathrm{~h}$ in mRPMI containing $0,10,100,1000 \mu \mathrm{g} / \mathrm{ml}$ ASP in the humidified $5 \% \mathrm{CO}_{2}$ incubator. After incubation, half of the cells (three wells) from the same sample were fixed with $0.5 \%(\mathrm{v} / \mathrm{v}$ ) paraformaldehyde (Beijing Dingguo Changsheng Biotech. Co. Ltd., Beijing, China) in PBS for $60 \mathrm{~min}$ and used as the control. All wells were washed once with mRPMI, and $100 \mu \mathrm{l}$ GRRBCs $\left(1.8 \times 10^{7} \mathrm{cells} / \mathrm{mL}\right.$ in $\left.\mathrm{mRPMI}\right)$ was added to each well. Phagocytosis was allowed to proceed for $30 \mathrm{~min}$ at $27^{\circ} \mathrm{C}$ in the humidified $5 \% \mathrm{CO}_{2}$ incubator. Then all wells were washed three times to remove non-ingested and nonattached GRRBCs. One hundred microliters of $0.2 \mathrm{M}$ Tris- $\mathrm{HCl}$ (Roche, Sigma-aldrich, China, pH 7.4 in $6 \mathrm{M}$ urea) were added to each well and left for $5 \mathrm{~min}$ at room temperature, then $100 \mu \mathrm{l}$ 2,4-diaminofluorence (Sigma, Beijing, China) substrate solution containing $0.27 \% \mathrm{H}_{2} \mathrm{O}_{2}$ was added to each well. The plate was incubated for $5 \mathrm{~min}$ at room temperature, and the O.D. was read at $608 \mathrm{~nm}$ using a microplate reader (VarioskanFlash, Thermo Scientific, China). Phagocytosis activity was calculated as O.D.test well - O.D.control well. Activation of phagocytosis was calculated as $100 \times$ [(phagocytosis activity in wells with ASP - phagocytosis activity in wells without ASP)/phagocytosis activity in wells without ASP].

Respiratory burst. A nitroblue tetrazolium (NBT) reduction method was adopted to assay the respiratory burst, followed by Wang et al. (2011a) with some modifications. Briefly, a $100 \mu$ l aliquot of leukocyte suspension $\left(5 \times 10^{6}\right.$ cells $\left./ \mathrm{mL}\right)$ was placed in a flatbottomed 96-well cell culture plate (Greiner Bio-one, Germany) and incubated for $3 \mathrm{~h}$ at $27^{\circ} \mathrm{C}$ in a humidified $5 \% \mathrm{CO}_{2}$ incubator. Non-adherent cells were removed by washing the cultures twice with phenol red-free HBSS. One hundred microliters of APS at 0, 10, 100, $1000 \mu \mathrm{g} / \mathrm{ml}$ in HBSS were added to three wells, and $100 \mu \mathrm{l}$ of Lipopolysaccahride (LPS, Sigma, Beijing, China) at $100 \mu \mathrm{g} / \mathrm{ml}$ in HBSS were added to another three wells to serve as positive control. Then the leukocytes were incubated for $2,6,12$, or $24 \mathrm{~h}$ in the humidified $5 \% \mathrm{CO}_{2}$ incubator. After incubation, a $100 \mu \mathrm{l}$ aliquot of nitroblue tetrazolium (NBT, $2 \mathrm{mg} / \mathrm{mL}$, Sigma, Beijing, China) was added to each well and incubated at $27^{\circ} \mathrm{C}$ for $30 \mathrm{~min}$. Then, the HBSS was discarded and the reaction was stopped by adding methanol. After washing twice with $70 \%(\mathrm{v} / \mathrm{v})$ methanol, the formazan formed in each well was dissolved by adding $120 \mu \mathrm{l}$ of $2 \mathrm{M} \mathrm{KOH}$ (Sigma-Aldrich, Beijing, China) and 140 $\mu l$ of dimethyl sulphoxide (DMSO, Sigma, Beijing, China). The optical density (O.D.) was measured at $690 \mathrm{~nm}$ using the microplate reader mentioned above. Respiratory burst 
activity was expressed as NBT reduction, expressed as O.D.690nm per $5 \times 10^{6}$ cells. Activation of respiratory burst was calculated as $100 \times$ [(O.D. in test cells - O.D. in control cells)/O.D. in control cells.

Bactericidal assay. The ability of head-kidney leukocytes to kill Edwardsiella tarda was assayed following Pohlenz et al. (2012) and Shoemaker et al. (1997) with some modifications. E. tarda was cultured in beef-extract peptone broth (BPB, Qingdao Hope Biol-Technology Co., Ltd., Qingdao, China) at $28^{\circ} \mathrm{C}$ for $24 \mathrm{~h}$, then centrifuged at $2000 \mathrm{~g}$ for $10 \mathrm{~min}$, after which the pellets were washed twice in sterile $0.85 \%$ sodium chloride, and resuspended in $4^{\circ} \mathrm{C}$ BPB. Bacteria suspension was calibrated to $1 \times 10^{8} \mathrm{cells} / \mathrm{mL}$ prior to use using a bacterial counter chamber, and was stored at $4^{\circ} \mathrm{C}$. One hundred microliters of leukocytes suspension $\left(5 \times 10^{6}\right.$ cells $/ \mathrm{mL}$ ) were added to each well in a sterile flat bottom 96 -well microplate. This microplate was incubated at $27^{\circ} \mathrm{C}$ for $2 \mathrm{~h}$ in a $5 \% \mathrm{CO}_{2}$ incubator for the attachment of macrophages, then washed twice with antibiotic free (af)-RPMI-1640. Then, $100 \mu \mathrm{l}$ of af-RPMI-1640 solution containing ASP were added to each corresponding well. The final concentration of ASP in wells was 0,100,1000,10000 $\mu \mathrm{g} / \mathrm{ml}$, respectively. Each ASP concentration was repeated in six wells. Twenty microliters of bacterial suspension in BPB was added to each well and the microplate was centrifuged at $150 \mathrm{~g}$ for $5 \mathrm{~min}$ to bring bacteria into contact with macrophages. The combined cell cultures (macrophages + bacteria) were incubated at $27^{\circ} \mathrm{C}$ for $0 \mathrm{~h}$ or $2.5 \mathrm{~h}$. After each incubation period, supernatants were removed and macrophages were lysed with $50 \mu \mathrm{l}$ of 0.2\% Tween 20 (Beijing Dingguo Changsheng Biotech. Co. Ltd., Beijing, China) to stop intracellular killing. Fresh BPB $(100 \mu \mathrm{l}$ per well) was added for $E$. tarda growth after macrophage lysis, and the plate was incubated for $18 \mathrm{~h}$ at $27^{\circ} \mathrm{C}$. After the incubation, 20 $\mathrm{ml}$ 3-[4,5-dimethylthiazol-2-yl]-2,5-diphenyl tetrazolium bromide (MTT, $1 \mathrm{mg} / \mathrm{mL}$, Sigma, Beijing, China) was added to each well and the plate was incubated for an additional $15 \mathrm{~min}$. Reduction of MTT by $E$. tarda surviving in macrophages was used as a measure of intracellular killing. Absorbance was read at $620 \mathrm{~nm}$ using a microplate reader. Bacterial concentrations were calculated by comparing the absorbance obtained for each well to a standard curve previously constructed (data not shown). Bactericidal activity [\% killing $=($ bacteria $0 \mathrm{~h}$ - bacteria $2.5 \mathrm{~h}) \times 100 /$ bacteria $0 \mathrm{~h}$ ] was computed for each well and was presented as mean \% killing per treatment.

Leukocyte proliferation. Leukocyte proliferation was measured according to Wang et al. (2011a) with minor modifications. The head-kidney leukocytes were resuspended in RPMI-1640 proliferation medium containing $10 \%$ FBS, $2 \%$ heat-inactivated grouper sera (45 ${ }^{\circ} \mathrm{C}$ for $\left.30 \mathrm{~min}\right), 100 \mathrm{IU} / \mathrm{mL}$ ampicillin, and $0.1 \mathrm{mg} / \mathrm{mL}$ streptomycin sulfate. A $90 \mu \mathrm{l}$ aliquot of proliferation medium containing $5 \times 10^{5}$ cells and $10 \mu \mathrm{l}$ ASP or LPS $(100 \mu \mathrm{g} / \mathrm{mL}$ mRPMI) was added to wells of a 96-well cell culture plate and incubated for $24 \mathrm{~h}$ or $48 \mathrm{~h}$ at $27^{\circ} \mathrm{C}$ in a humidified $5 \% \mathrm{CO}_{2}$ incubator. The final concentration of ASP in the 96-well plate was $0,100,1000,10000 \mu \mathrm{g} / \mathrm{ml}$, respectively. Then, $20 \mu \mathrm{l}$ of MTT $(1 \mathrm{mg} / \mathrm{mL})$ was added to each well and incubated for $4 \mathrm{~h}$ at $27^{\circ} \mathrm{C}$. The plate was then centrifuged at 500 $g$ for $10 \mathrm{~min}$ at $4^{\circ} \mathrm{C}$. The supernatant was discarded, and the formazan crystals in each well were dissolved by adding $200 \mu \mathrm{L}$ DSO and $25 \mu \mathrm{l}$ of glycine buffer ( $0.1 \mathrm{M}$ glycine, $0.1 \mathrm{M} \mathrm{NaCl}, \mathrm{pH} 10.5)$. The contents in the wells were thoroughly mixed on a microoscillator (ZW-A, Youlian Instrument Research Institute, Jiangsu, China), and the O.D. at $550 \mathrm{~nm}$ of the resulting suspension was measured in the microplate reader mentioned above.

Statistical analysis. Data were analyzed using one-way analysis of variance, followed by Tukey's Studentized Range (HSD) test to determine possible significant differences among treatments. Statistical analyses were conducted using SAS 9.4 (SAS Institute, Cary, NC, USA) software. Differences among treatments were considered significant at $P<0.05$. Data in figures were represented as means \pm standard deviation $(n=3$, leukocytes from 10 fish were pooled as one replicate). 


\section{Results}

Phagocytic activity. Phagocytic activity and activation of phagocytosis are presented in Fig. 1a, b. Leukocytes incubated in 10, $100 \mu \mathrm{g} / \mathrm{mL}$ ASP for 2, 6, 12, and $24 \mathrm{~h}$ exhibited significantly higher phagocytic activity than control. Phagocytic activity of leukocytes incubated in $1000 \mu \mathrm{g} / \mathrm{mL}$ ASP for 2, $6 \mathrm{~h}$ was not significantly higher, but for $12,24 \mathrm{~h}$ was significantly higher than control. Leukocytes incubated in $100 \mu \mathrm{g} / \mathrm{ml}$ ASP exhibited the highest level of phagocytic activity among all the treatment groups at each incubation time. Activation of phagocytosis (Fig. 1b) of leukocytes incubated in $100 \mu \mathrm{g} / \mathrm{ml} \mathrm{ASP}$ was highest among all the ASP incubated groups. Activation of phagocytosis in $1000 \mu \mathrm{g} / \mathrm{L}$ group was lower than the other two groups at $2,6 \mathrm{~h}$ then increased to $10 \mu \mathrm{g} / \mathrm{mL}$ level at $12,24 \mathrm{~h}$. Data in Fig. $1 \mathrm{a}, \mathrm{b}$ indicate that $12 \mathrm{~h}$ incubation with ASP is suitable for the in vitro leukocytes phagocytic test.
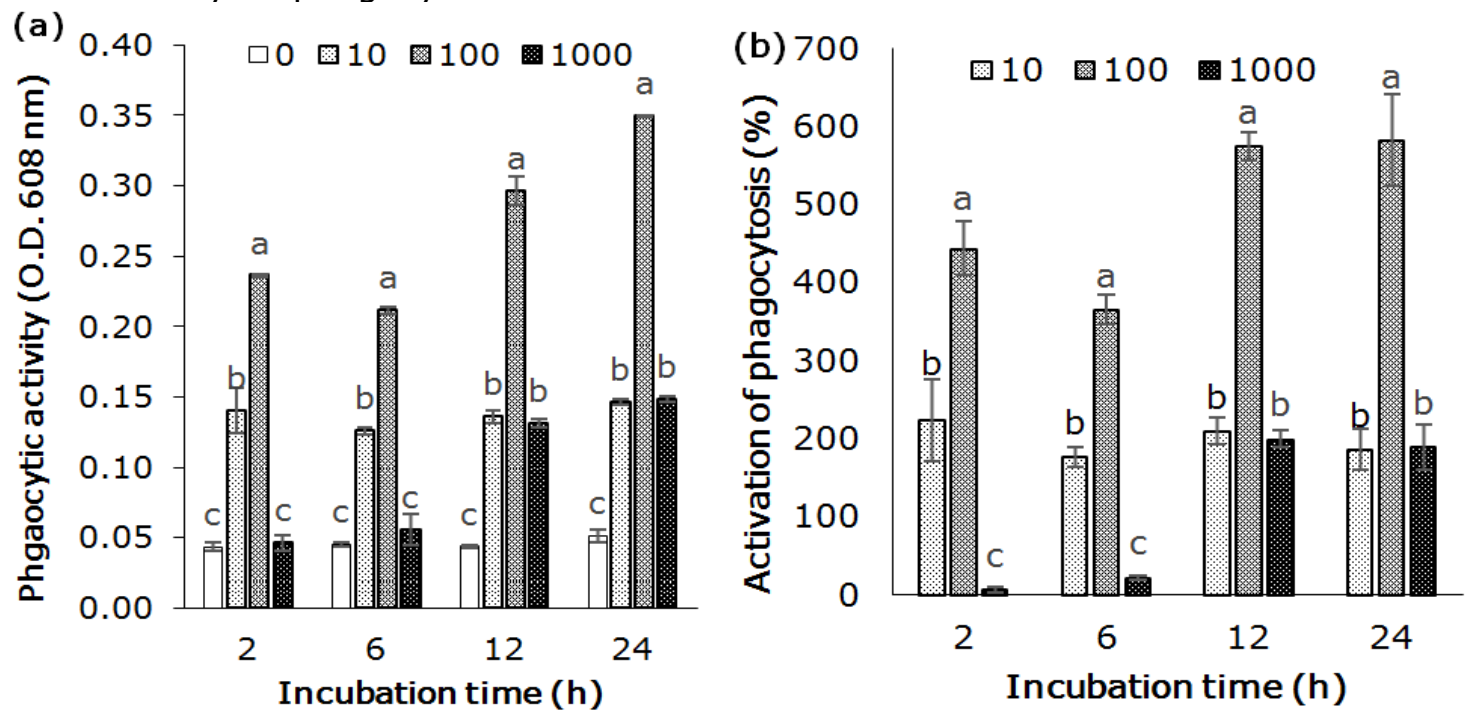

Fig. 1. Head kidney leukocytes phagocytic activity (a) and activation of phagocytosis (b) of $E$. malabaricus after 2, 6, 12, and $24 \mathrm{~h}$ incubation in $0,10,100,1000 \mu \mathrm{g} / \mathrm{ml} \mathrm{ASP}$. Activation of phagocytosis (\%) was calculated as [(phagocytosis activity in wells with ASP - phagocytosis activity in wells without ASP)/phagocytosis activity in wells without ASP] $\times 100$. Each bar represents mean ( \pm SD) of three replicates. Bars not sharing a common letter in the same incubation time are significantly different based on analysis of variance $(P<0.05)$ followed by Tukey's Studentized Range (HSD) test. ASP, Angelica sinensis polysaccharide.

Respiratory burst. The respiratory burst activity is presented in Fig. 2a. Compared with control group, LPS significantly stimulated respiratory burst activity, which indicates the vitality of leukocytes was normal in vitro. Both ASP and LPS significantly stimulated leukocyte respiratory burst at each incubation time. Leukocytes incubated in $100 \mu \mathrm{g} / \mathrm{mL}$ ASP exhibited highest respiratory burst activity among all groups at each incubation time. Data in Fig. $2 b$ show that the activation of respiratory burst in $100 \mu \mathrm{g} / \mathrm{mL}$ group is the highest among all groups at each incubation time. In terms of leukocytes incubation time, two hours incubation with ASP is enough to test ASP's effect on leukocytes respiratory burst in vitro. 

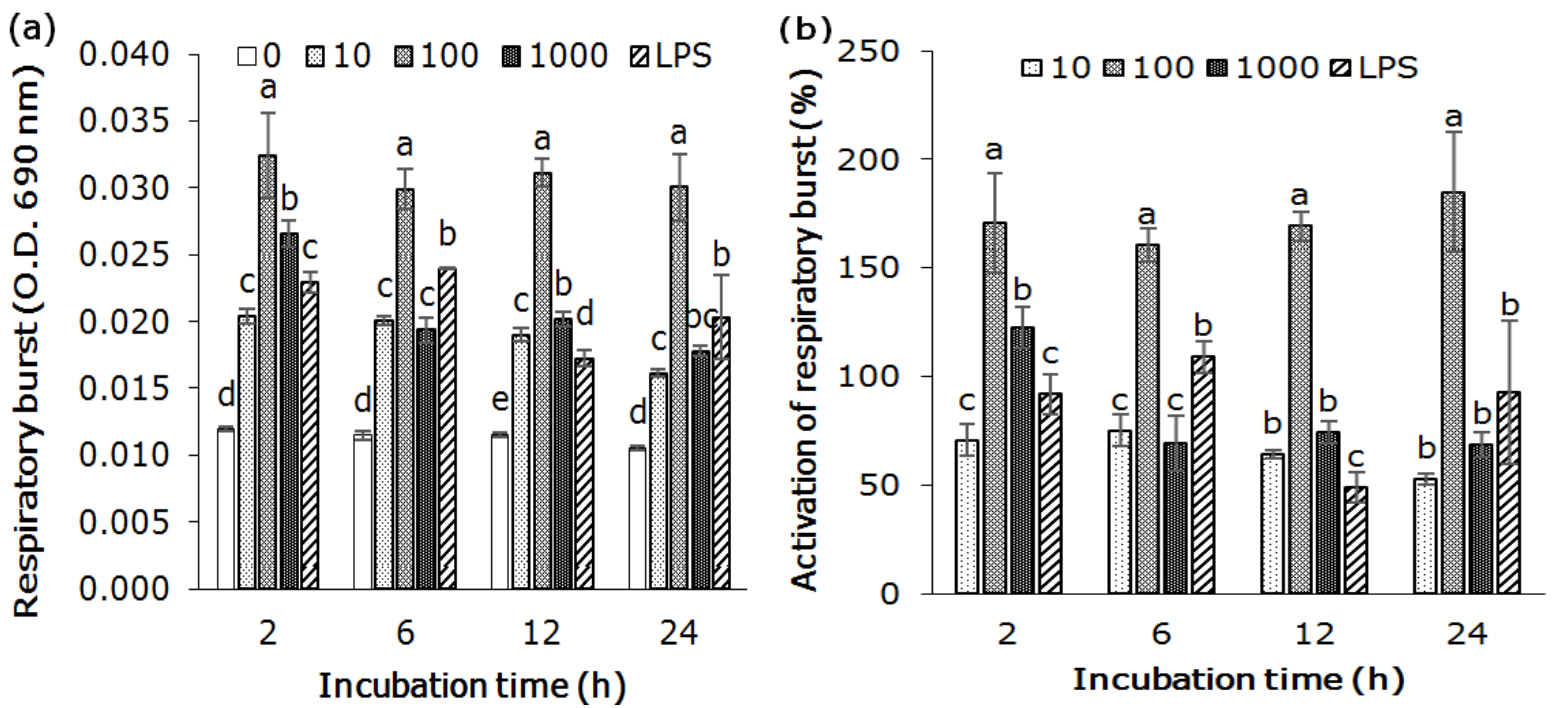

Fig. 2. Head kidney leukocytes respiratory burst activity (a) and activation of respiratory burst (b) of E. malabaricus after $2,6,12$, and $24 \mathrm{~h}$ incubation in $0,10,100,1000 \mu \mathrm{g} / \mathrm{ml} \mathrm{ASP}$ or $100 \mu \mathrm{g} / \mathrm{ml}$ LPS. Activation of respiratory burst (\%) was calculated as [(O.D. in test cells - O.D. in control cells) / O.D. in control cells] $\times 100$. Each bar represents mean $( \pm S D)$ of three replicates. Bars not sharing a common letter in the same incubation time are significantly different based on analysis of variance $(P<0.05)$ followed by Tukey's Studentized Range $(\mathrm{HSD})$ test. ASP, Angelica sinensis polysaccharide. LPS, lipopolysaccharide.

Bactericidal assay. Bactericidal activity is presented in Fig. 3a. Compared with control, leukocytes bactericidal activity was significantly higher after $24 \mathrm{~h}$ incubation with ASP. Leukocytes incubated with ASP at $1000 \mu \mathrm{g} / \mathrm{mL}$ exhibited the highest bactericidal activity and activation of bactericidal activity (Fig. 3a, b). Similar bactericidal activity and activation of bactericidal activity were observed in leukocytes cultured in 100 and 10000 $\mu \mathrm{g} / \mathrm{ml}$ ASP (Fig. 3a, b).
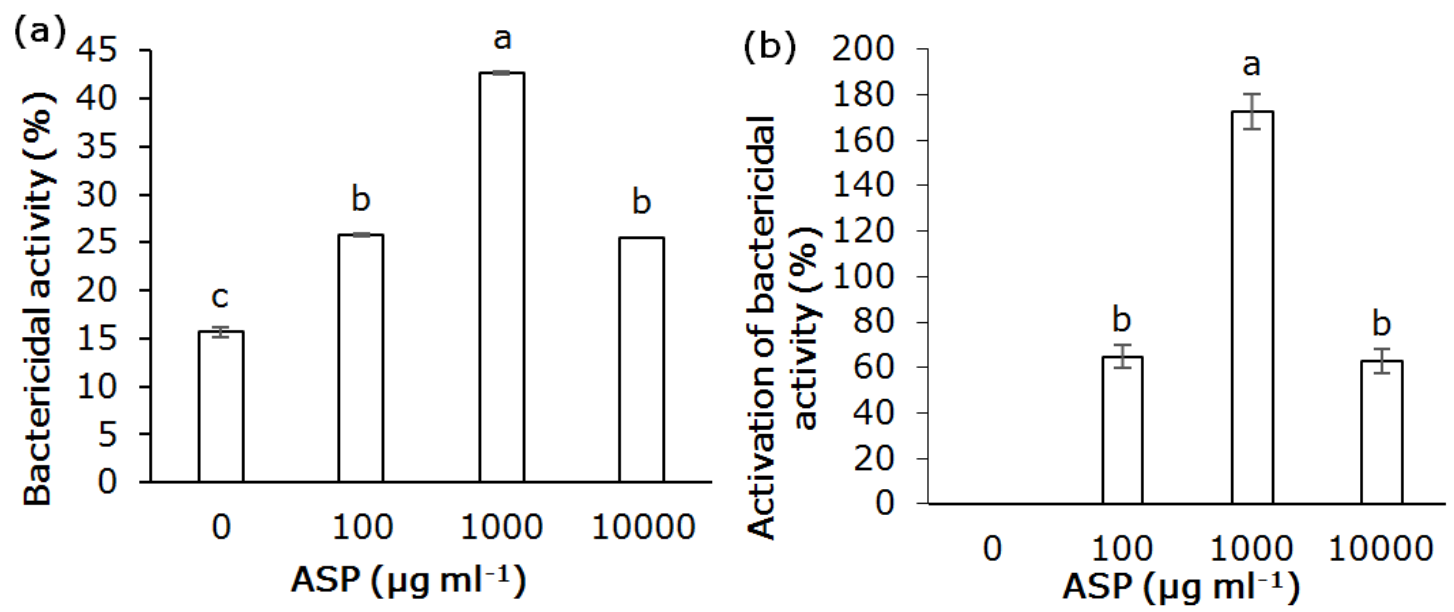

Fig. 3. Head kidney leukocytes bactericidal activity (a) and activation of bactericidal activity (b) of E. malabaricus after $24 \mathrm{~h}$ incubation in $0,10,100,1000 \mu \mathrm{g} / \mathrm{ml}$ ASP. Bactericidal activity was calculated as [(bacteria $0 \mathrm{~h}-$ bacteria $2.5 \mathrm{~h}$ ) / bacteria $0 \mathrm{~h}$ ] $\times 100$. Activation of bactericidal activity (\%) was calculated as [(bactericidal activity in wells with ASP - bactericidal activity in wells without ASP) / bactericidal activity in wells without ASP] $\times 100$. Each bar represents mean $( \pm S D)$ of three replicates. Bars not sharing a common letter are significantly different based on analysis of variance $(P<0.05)$ followed by Tukey's Studentized Range $(\mathrm{HSD})$ test. ASP, Angelica sinensis polysaccharide. 
Leukocytes proliferation. The stimulated leukocytes proliferation cultured with ASP or LPS for $24 \mathrm{~h}$ and $48 \mathrm{~h}$ was observed in Fig. 4a. Leukocytes incubated in 1000, 10000 $\mu \mathrm{g} / \mathrm{ml}$ ASP for 24, $48 \mathrm{~h}$ exhibited significantly higher proliferation than the control. Leukocytes incubated in $100 \mu \mathrm{g} / \mathrm{ml} \mathrm{ASP}$ exhibited similar proliferation with control, but statistical differences between $100 \mu \mathrm{g} / \mathrm{ml}$ ASP and control were observed at $48 \mathrm{~h}$. Activation of leukocytes proliferation varied significantly at $24 \mathrm{~h}$, which was the highest in $10000 \mu \mathrm{g} / \mathrm{mL}$, followed by $1000 \mu \mathrm{g} / \mathrm{mL}$, and $100 \mu \mathrm{g} / \mathrm{mL}$ was the lowest (Fig. 4b). After $48 \mathrm{~h}$ incubation, activation of proliferation in $100 \mu \mathrm{g} / \mathrm{ml}$ ASP was the lowest but no statistically significant differences were observed among 1000, $10000 \mu \mathrm{g} / \mathrm{ml} \mathrm{ASP}$, and $100 \mu \mathrm{g} / \mathrm{mL}$ LPS groups (Fig. 4b). LPS exerted stronger stimulation on leukocyte proliferation than ASP in the same concentration $(100 \mu \mathrm{g} / \mathrm{ml}$ ) (Fig. 4a, b). Data in Fig. $4 a, b$ indicate that $24 \mathrm{~h}$ incubation with ASP is apt for the in vitro leukocyte proliferation test.
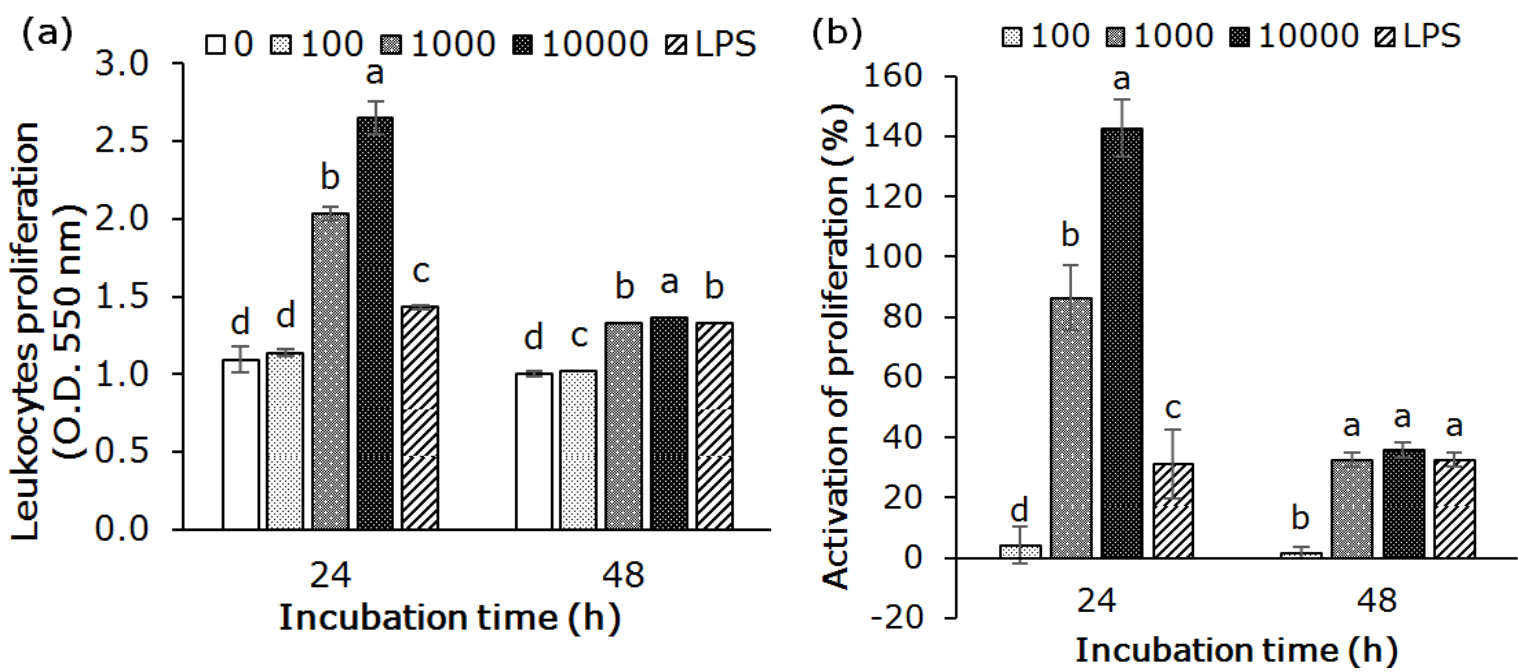

Fig. 4. Head kidney leukocytes proliferation (a) and activation of proliferation (b) of $E$. malabaricus after 24 and $48 \mathrm{~h}$ incubation in $0,100,1000,10000 \mu \mathrm{g} / \mathrm{ml}$ ASP or $100 \mu \mathrm{g} / \mathrm{ml} \mathrm{LPS.} \mathrm{Activation} \mathrm{of}$ proliferation (\%) was calculated as [(proliferation in wells with ASP or LPS - proliferation in wells without ASP and LPS) / proliferation in wells without ASP and LPS] $\times 100$. Each bar represents mean $( \pm \mathrm{SD})$ of three replicates. Bars not sharing a common letter in the same incubation time are significantly different based on analysis of variance $(P<0.05)$ followed by Tukey's Studentized Range (HSD) test. ASP, Angelica sinensis polysaccharide. LPS, lipopolysaccharide.

\section{Discussion}

Botanical polysaccharides isolated from a wide range of flora species, including higher plants, mushrooms, lichens, and algae, exhibit robust immunostimulatory properties (Schepetkin et al., 2006). Most polysaccharides derived from higher plants are relatively nontoxic and exhibit limited side effects (Ovodov, 1998), that are considered a major issue deriving from immunomodulatory bacterial polysaccharides and synthetic compounds. To date, several studies have demonstrated immunity enhancement in aquatic animals with dietary supplemental higher plant-derived polysaccharide extracted from Astragalus membranaceus in sea cucumber Apostichopus japonicas (Wang et al., 2009), spotted maigre Nibea albiflora (Wang et al., 2012), yellow catfish Pelteobagrus fulvidraco (Bai et al., 2012), and tilapia Oreochromis niloticus (Zahran et al., 2014), A. sinensis in grouper E. malabaricus (Wang et al., 2012), Ficus carica in grass carp Ctenopharyngodon idella (Yang et al., 2015), Druio zibethinus in shrimp Penaeus mondon (Pholdaeng et al., 2010), and Panax ginseng in shrimp Litopenaeus vannamei (Liu et al., 2011). This indicates that plant-derived polysaccharides provide potential positive effects in aquaculture.

Plant-derived non-starch polysaccharide is not easily hydrolyzed by enzymatic systems secreted by digestive tract or gut microbiota of higher animals (Grosell et al., 2011). Consequently, such incompletely hydrolyzed polysaccharides serve as additional 
immunostimulants (Westerhof et al., 2000). Although oral administration of aforementioned polysaccharide affects the immunity of aquatic animals, there is still no evidence that the prototype of these polysaccharides possess any immunostimulatory properties in aquatic animals. Our findings demonstrated that the ASP prototype can dose-dependently boost leukocyte phagocytic, respiratory burst, bactericidal activity and proliferation of $E$. malabaricus.

Macrophages play a vital role in host defenses against microorganisms by engulfing microbes and killing them by producing reactive oxygen species (ROS) during respiratory burst (Iwama et al., 1996). The phagocytic, respiratory burst, and bactericidal activity are useful indicators to assess the immune function of phagocytic cells, including circulating monocytes, neutrophils, and tissue macrophages. In the present study, the adherence method (Field et al., 1995) was used to harvest $E$. malabaricus head-kidney macrophages, which were further morphologically confirmed using an inverted microscope (Leica DMI4000B, Germany). Our results show that significantly high phagocytic and respiratory burst activity was observed in macrophages incubated with ASP, compared with control (Fig. 1, 2). Furthermore, ASP boosted macrophages phagocytic and respiratory burst activity in a dose-dependent manner: macrophages incubated in $100 \mu \mathrm{g} / \mathrm{ml}$ ASP exhibited the highest activity, while incubated in lower (10 $\mu \mathrm{g} / \mathrm{ml})$ and higher $(1000 \mu \mathrm{g} / \mathrm{ml})$ dosage of ASP exhibited relatively weaker activity. ASP exerted stronger activity to stimulate the respiratory burst of macrophages than LPS in the same concentration (Fig. 2a, b). Dietary ASP $(500,3000 \mathrm{mg} / \mathrm{kg}$ ) enhanced both phagocytic and respiratory burst activity significantly in E. malabaricus head kidney leukocytes (Wang et al., 2011a). Dietary Astragalus polysaccharides significantly upregulated whole blood phagocytic activity and respiratory burst activity in Nile tilapia O. niloticus (Zahran et al. 2014). Dietary supplemental $A$. membranaceus polysaccharide significantly enhanced phagocytic activity and ROS production of coelomocytes in sea cucumber A. japonicas (Wang et al., 2009). Intraperitoneal injection of fucoidan, a polysaccharide mainly produced by brown algae, significantly enhanced phagocytic activity and respiratory burst activity in tilapia O. niloticus (Isnansetyo et al., 2015). These findings indicate that botanical polysaccharides upregulate phagocytic capacity of macrophages in aquatic animals.

However, the process of respiratory burst cannot kill all pathogens. For instance, Renibacterium salmoninarum can survive in mononuclear phagocytes depending on its ability to move from the phagosome into the cytoplasm (Gutenberger et al., 1997). Therefore, bactericidal assay is a further verification of phagocytized bacteria mortality in macrophages. Mosmann (1983) developed a rapid colorimetric assay based on MTT that measures only live cells utilizing spectrophotometry. This method was proved to be accurate to detect live Escherichia coli (Wang et al., 2011b). In the present study, ASP can significantly enhance the bactericidal activity of $E$. malabaricus head kidney phagocytes (Fig. 3a, b). Macrophages incubated in $1000 \mu \mathrm{g} / \mathrm{ml}$ ASP exhibited the highest bactericidal activity (Fig. 3a, b). So far, influence of botanical polysaccharides on macrophage bactericidal activity of other animals has not been found.

The ASP prototype is also a lymphocytes proliferation enhancer. The proliferation of $T$ cells in BALB/c mice was directly activated by ASP, while B cells were not influenced, which indicated that ASP was T cell specific mitogenicity (Yang et al., 2006). Our results of leukocytes proliferation (Fig. 4a, b) indicated that E. malabaricus head kidney leukocytes were responsive to both LPS, which is B cell mitogenicity (Sizemore et al., 1984), and ASP, a T cell specific mitogenicity. These results reinforce the conclusion that teleost fish possess lymphocyte populations analogous in many respects to the $T$ cells and B cells of mammals (Iwama et al., 1996).

In conclusion, ASP can enhance the in vitro phagocytic, respiratory burst, bactericidal, and proliferation responses of E. malabricus head kidney leukocytes, indicating that ASP prototype provides potential benefits on cellular immunity of E. malabaricus. The findings in this paper provide data showing the possibility that intraperitoneal injection of ASP could contribute to the immunity of E. malabaricus. Further intraperitoneal injection tests are recommended to verify the immune efficacy of ASP on E. malabaricus. 


\section{Acknowledgments}

This research was financially supported by National Natural Science Foundation of China (grant number: 31270456), Major Project of National Spark Plan (grant number 2013GA610002), and Tianjin Innovation Team Fund (grant number TD12-5018). Special thanks to the staff, Mr. Shusen Zhang, Yonghai Yang, Xuequan Yu, and Zhenhui Wang, in Tianjin Haifa Seafood Co. Ltd. for their assistance during the rearing of grouper. The authors would like to extend their thanks to those who have taken time to critically review this manuscript.

\section{References}

Bai, D., Wu, X., Zhu, G., Guo, Y., Yang, G., Ning, B., Xing, K., 2012. Astragalus polysaccharides enhance cellular immune response and disease resistance in yellow catfish. Isr. J. Aquacult.-Bamidgeh, 64:688-694.

Bhuvaneswari, R. and Balasundaram, C., 2006. Traditional indian herbal extracts used in vitro against growth of the pathogenic bacteria - Aeromonas hydrophila. Isr. J. Aquacult.-Bamidgeh, 58(2):89-96.

Cao, W., Li, X., Wang, X., Li, T., Chen, X., Liu, S., Mei, Q., 2010. Characterizations and anti-tumor activities of three acidic polysaccharides from Angelica sinensis (Oliv.) Diels. Int. J. Biol. Macromol., 46, 115-122.

Chen, Y., Duan, J., Qian, D., Guo, J., Song, B., Yang, M., 2010. Assessment and comparison of immunoregulatory activity of four hydrosoluble fractions of Angelica sinensis in vitro on the peritoneal macrophages in ICR mice. Int. Immunopharmacol., 10, 422-430.

Field, M.D.R., Hutchinson, T.H., Manning, M.J., 1995. Development of adherence techniques for collecting kidney phagocytes from marine fish (Limanda limanda L.). Fish Shellfish Immunol., 5, 505-517.

Gebran, S., Romano, E., Pons, H., Cariani, L., Soyano, A., 1992. A modified colorimetric method for the measurement of phagocytosis and antibody-dependent cell cytotoxicity using 2, 7-diaminofluorene. J. Immunol. Methods. 151, 255-260.

Grosell, M., Farrell, A.P., Brauner, C.J., 2011. The Multifunctional Gut of Fish: The Multifunctional Gut of Fish. Academic Press.

Gutenberger, S., Duimstra, J., Rohovec, J., Fryer, J., 1997. Intracellular survival of Renibacterium salmoninarum in trout mononuclear phagocytes. Dis. Aquat. Org., 28, 93106.

Harikrishnan, R., Balasundaram, C., Heo, M.-S., 2011. Impact of plant products on innate and adaptive immune system of cultured finfish and shellfish. Aquaculture. 317, 115.

Isnansetyo, A., Fikriyah, A., Kasanah, N., Murwantoko, 2015. Non-specific immune potentiating activity of fucoidan from a tropical brown algae (Phaeophyceae), Sargassum cristaefolium in tilapia (Oreochromis niloticus). Aquacult. Int., 1-13.

Iwama, G., Nakanishi, T., 1996. The fish immune system: organism, pathogen, and environment. Academic Press.

Jin, M., Zhao, K., Huang, Q., Xu, C., Shang, P., 2012. Isolation, structure and bioactivities of the polysaccharides from Angelica sinensis (Oliv.) Diels: A review. Carbohydr. Polym., 89, 713-722.

Liu, X.-L., Xi, Q.-Y., Yang, L., Li, H.-Y., Jiang, Q.-Y., Shu, G., Wang, S.-B., Gao, P., Zhu, X.-T., Zhang, Y.-L., 2011. The effect of dietary Panax ginseng polysaccharide extract on the immune responses in white shrimp, Litopenaeus vannamei. Fish Shellfish Immunol., 30, 495-500.

Mosmann, T., 1983. Rapid colorimetric assay for cellular growth and survival: application to proliferation and cytotoxicity assays. J. Immunol. Methods. 65, 55-63.

Ovodov, I., 1998. Polysaccharides of flower plants: structure and physiological activity. Bioorg. Khim., 24, 483-501.

Pholdaeng, K., Pongsamart, S., 2010. Studies on the immunomodulatory effect of polysaccharide gel extracted from Durio zibethinus in Penaeus monodon shrimp against 
Vibrio harveyi and WSSV. Fish Shellfish Immunol., 28, 555-561.

Pohlenz, C., Buentello, A., Mwangi, W., Gatlin Iii, D.M., 2012. Arginine and glutamine supplementation to culture media improves the performance of various channel catfish immune cells. Fish Shellfish Immunol., 32, 762-768.

Schepetkin, I.A., Quinn, M.T., 2006. Botanical polysaccharides: macrophage immunomodulation and therapeutic potential. Int. Immunopharmacol., 6, 317-333.

Shoemaker, C.A., Klesius, P.H., Plumb, J.A., 1997. Killing of Edwardsiella ictaluri by macrophages from channel catfish immune and susceptible to enteric septicemia of catfish. Vet. Immunol. Immunopathol., 58, 181-190.

Sizemore, R., Miller, N., Cuchens, M., Lobb, C., Clem, L., 1984. Phylogeny of lymphocyte heterogeneity: the cellular requirements for in vitro mitogenic responses of channel catfish leukocytes. J. Immunol., 133, 2920-2924.

Van Hai, N., 2015. The use of medicinal plants as immunostimulants in aquaculture: $A$ review. Aquaculture. 446, 88-96.

Wang, Q., Xing, K., Zhao, H., Chen, C., Wu, Z., Ma, S., 2012. Dietary Angelica sinensis polysaccharide on innate immunity and disease resistance against Edwardsiella tarda of Epinephelus malabaricus. Period. Ocean Univ. China/Zhongguo Haiyang Daxue Xuebao. 42, 15-21.

Wang, Q., Chen, C., Guo, Y., Zhao, H., Sun, J., Ma, S., Xing, K., 2011a. Dietary polysaccharide from Angelica sinensis enhanced cellular defence responses and disease resistance of grouper Epinephelus malabaricus. Aquacult. Int., 19, 945-956.

Wang, T., Sun, Y., Jin, L., Xu, Y., Wang, L., Ren, T., Wang, K., 2009. Enhancement of non-specific immune response in sea cucumber (Apostichopus japonicus) by Astragalus membranaceus and its polysaccharides. Fish Shellfish Immunol., 27, 757-762.

Wang X., Ding L., Yan M., Chai X., Lu R., Wang Q., Li F., 2012. Polysaccharides, Saponins, and Water Decoction of Astragalus membranaceus Significantly Enhance the Non-Specific Immune Response of Spotted Maigre (Nibea albiflora). Israeli J. Aquacult. Bamidgeh, 64, 743-748.

Wang, Z., Gao, Q., Ma, C., Li, Y., 2011b. Experimental study on the application of MTT colorimetric method in counting live Escherichia coli. Acta Sci. Circumstant./Huanjing Kexue Xuebao. 31, 2642-2650.

Westerhof, W., Das, P., Middelkoop, E., Verschoor, J., Storey, L., Regnier, C., 2000. Mucopolysaccharides from psyllium involved in wound healing. Drugs Exp. Clin. Res., 27, 165-175.

Yang, T., Jia, M., Meng, J., Wu, H., Mei, Q., 2006. Immunomodulatory activity of polysaccharide isolated from Angelica sinensis. Int. J. Biol. Macromol., 39, 179-184.

Yang, X., Zhao, Y., Lv, Y., 2008. In vivo macrophage activation and physicochemical property of the different polysaccharide fractions purified from Angelica sinensis. Carbohydr. Polym., 71, 372-379.

Yang, X., Guo, J.L., Ye, J.Y., Zhang, Y.X., Wang, W., 2015. The effects of Ficus carica polysaccharide on immune response and expression of some immune-related genes in grass carp, Ctenopharyngodon idella. Fish Shellfish Immunol., 42, 132-137.

Ye, Y.N., Liu, E.S.L., Li, Y., So, H.L., Cho, C.C.M., Sheng, H.P., Lee, S.S., Cho, C.H., 2001. Protective effect of polysaccharides-enriched fraction from Angelica sinensis on hepatic injury. Life Sci., 69, 637-646.

Zahran, E., Risha, E., AbdelHamid, F., Mahgoub, H.A., Ibrahim, T., 2014. Effects of dietary Astragalus polysaccharides (APS) on growth performance, immunological parameters, digestive enzymes, and intestinal morphology of Nile tilapia (Oreochromis niloticus). Fish Shellfish Immunol., 38, 149-157. 